\title{
HUBUNGAN PERILAKU PETUGAS KEBERSIHAN DENGAN TINDAKAN PENANGANAN LIMBAH PADAT (Studi di RSUD Syarifah Ambami Rato Ebu Bangkalan Tahun 2018) \\ Dwi Shinta Nurefendi, Sri Mardoyo, Marlik
}

\section{ABSTRAK}

Rumah sakit merupakan tempat pelayanan kesehatan yang menghasilkan berbagai jenis limbah salah satunya limbah padat baik medis maupun non medis. Limbah padat tersebut perlu dilakukan pengelolaan limbah padat sesuai dengan peraturan Kepmenkes 1204 tahun 2004, dengan tujuan untuk menghindari terjadinya pencemaran lingkungan dan penularan penyakit. Untuk menghindari hal tersebut maka petugas kebersihan harus memiliki perilaku yang baik dalam melakukan penanganan limbah padat. Karena dengan adanya pengetahuan dan sikap yang dimiliki diharapkan petugas dapat melakukan suatu tindakan. Penelitian ini bertujuan untuk mengetahui hubungan perilaku petugas kebersihan dengan tindakan penanganan limbah padat di RSUD Syarifah Ambami Rato Ebu Bangkalan.

Jenis penelitian ini adalah penelitian observasional secara analitik dengan desain penelitian cross sectional. Prosedur pengumpulan data dilakukan dengan observasi terhadap penanganan limbah padat dan wawancara tentang pengetahuan dan sikap petugas kebersihan. Sampel dalam penelitian ini sebanyak 49 petugas kebersihan di rumah sakit. Sampel diambil secara simple random sampling. Selanjutnya data yang sudah dikumpulkan dianalaisis univariat dan bivariat dengan uji statistik yaitu Kendall tau.

Hasil penelitian menunjukkan bahwa sebagian besar petugas kebersihan memiliki tingkat pengetahuan dan sikap yang baik yaitu sebesar $77,55 \%$ dan $63,27 \%$ petugas kebersihan memiliki tindakan yang cukup baik. Ada hubungan tingkat pengetahuan dan sikap petugas kebersihan dengan tindakan penanganan limbah padat. Berdasarkan analisis dengan menggunakan uji Kendall tau didapatkan hasil nilai $\rho$ value $=0,04$ kurang dari $a=0,05$ yang berarti ada hubungan antara sikap dengan tindakan penanganan limbah padat pada petugas kebersihan.

Hendaknya rumah sakit memberikan peraturan yang tegas terkait penanganan limbah padat dan perlu diadakan pelatihan atau sosialisai pada petugas kebersihan tentang penanganan limbah padat secara rutin.

Kata kunci: rumah sakit, petugas kebersihan, penaganan limbah padat

\section{PENDAHULUAN}

Rumah sakit merupakan tempat Informasi Tahun 2017 rumah sakit yang pelayanan kesehatan yang menghasilkan berada di Jawa Timur sebesar 373 berbagai jenis limbah baik limbah padat, rumah sakit, namun hanya terdapat 5 cair maupun gas. Jenis limbah padat rumah sakit yang melakukan yang dihasilkan rumah sakit dibagi pengelolaan limbah padat medis sesuai menjadi dua yaitu sampah medis dan dengan standart. non medis. Berdasarkan Pusat Data dan 
Limbah rumah sakit yang tidak terbuka yang dapat menimbulkan dikelola dengan baik dapat gangguan estetika.

mengakibatkan pencemaran lingkungan

Petugas kebersihan dalam dan berdampak pada kesehatan yang melakukan penanganan limbah padat berisiko menimbulkan infeksi virus tidak menggunakan Alat Pelindung Diri HIV/AIDS, hepatitis $B$, dan hepatitis $C$. Maka perlu dilakukan penanganan (APD) yang dapat menimbulkan kecelakaan. Hal tersebut terbukti dari limbah padat. Penanganan limbah padat hasil wawancara dengan petugas di rumah sakit perlu adanya sumber sanitasi bahwa pada tahun 2017 dan daya manusia yang mengelolah limbah 2018 pernah terjadi kecelakaan rumah sakit dilakukan oleh sumber daya (tertusuk) terhadap petugas kebersihan. manusia yaitu petugas kebersihan. Diharapkan petugas kebersihan dapat berperilaku sesuai dengan persyaratan penanganan limbah padat (Sudiharti, 2012).

Berdasarkan hasil survei

METODE PENELITIAN

Jenis penelitian adalah observasional analitik dengan pendekatan cross sectional. Penelitian dilakukan di RSUD Syarifah Ambami Rato pendahuluan yang dilakukan di RSUD Syarifah Ambami Rato Ebu Bangkalan pada tanggal 24 Januari 2018. Sampah medis yang dihasilkan sebanyak 200,45 $\mathrm{kg} /$ hari sedangkan limbah nonmedis sebanyak 324,30 kg/hari. Pada proses pengangkutan limbah padat masih ditemukannya petugas kebersihan yang melakukan pencampuran antara sampah medis dan non medis di satu wadah kantong plastik dengan alasan untuk mempemudah proses pengangkutan. Masih ditemukan pemakaian troli dalam keadaan terbuka. Konstruksi tempat pengumpulan sampah dalam keadaan Ebu Bangkalan dengan sampel sebanyak 49 petugas kebersihan. Teknik pengambilan sampel dengan cara simple random sampling. Data diperoleh dari hasil observasi dan wawancara diolah dalam bentuk tabel dan dianalisis menggunakan uji kendall tau.

\section{HASIL PENELITIAN}

1. Tingkat Pengetahuan

Tingkat pengetahuan petugas kebersihan di RSUD Syarifah Ambami Rato Ebu Bangkalan dengan kriteria baik sebesar 77,55\% (38 orang), terdapat 14,29\% (7 orang) yang 
memiliki pengetahuan cukup, dan ada $8,16 \%$ (4 orang) dengan pengetahuan kurang.

2. Sikap

Sikap petugas kebersihan di RSUD Syarifah Ambami Rato Ebu Bangkalan dengan kriteria baik sebesar $77,55 \%$ (38 orang), sikap cukup sebesar
$18,37 \%$ (9 orang), dan 4,08\% (2 orang) memiliki sikap kurang.

3. Tindakan

Tindakan petugas kebersihan di RSUD Syarifah Ambami Rato Ebu Bangkalan dengan kriteria cukup sebesar 63,27\% (31 orang) dan $36,73 \%$ (18 orang) mempunyai tindakan baik.

4. Hubungan pengetahuan petugas kebersihan dengan tindakan penanganan limbah padat

\section{Tabel 1}

HUBUNGAN PENGETAHUAN PETUGAS KEBERSIHAN DENGAN TINDAKAN PENANGANAN LIMBAH PADAT DI RSUD SYARIFAH AMBAMI RATO EBU BANGKALAN TAHUN 2018

\begin{tabular}{|c|c|c|c|c|c|c|}
\hline \multirow{3}{*}{ Pengetahuan } & \multicolumn{4}{|c|}{ Tindakan Penanganan Limbah Padat } & \multirow{2}{*}{\multicolumn{2}{|c|}{ Total }} \\
\hline & \multicolumn{2}{|c|}{ Cukup } & \multicolumn{2}{|c|}{ Baik } & & \\
\hline & Frek & $\%$ & Frek & $\%$ & Frek & $\%$ \\
\hline Kurang & 2 & 4,1 & 2 & 4,1 & 4 & 8,2 \\
\hline Cukup & 2 & 4,1 & 5 & 10,2 & 7 & 14,3 \\
\hline Baik & 27 & 55,1 & 11 & 22,4 & 38 & 77,6 \\
\hline Total & 31 & 63,26 & 18 & 36,74 & 49 & 100 \\
\hline
\end{tabular}

Berdasarkan tabel 1 sebagian besar petugas kebersihan memiliki tindakan penanganan limbah padat cukup dengan pengetahuan baik yaitu sebesar $55,1 \%$ (27 orang), tindakan cukup dengan pengetahuan cukup dan kurang sebanyak 4,1\% (2 orang). Sedangkan untuk tindakan penanganan limbah padat baik dengan pengetahuan baik yaitu sebesar 22,4\% (11 orang), tindakan baik dengan pengetahuan cukup sebesar $10,2 \%$ (5 orang), dan 4,1\% (2 orang) memiliki tindakan baik dengan pengetahuan yang kurang.

Berdasarkan analisis dengan menggunakan uji Kendall tau didapatkan hasil nilai $\rho$ value $=0,04$ kurang dari $a=0,05$ yang berarti ada hubungan antara pengetahuan 
dengan tindakan penanganan limbah padat pada petugas kebersihan di
RSUD Syarifah Ambami Rato Ebu Bangkalan tahun 2018.

5. Hubungan sikap petugas kebersihan dengan tindakan penanganan limbah padat

Tabel 2

HUBUNGAN SIKAP PETUGAS KEBERSIHAN DENGAN TINDAKAN PENANGANAN LIMBAH PADAT DI RSUD SYARIFAH AMBAMI RATO EBU BANGKALAN TAHUN 2018

\begin{tabular}{|c|c|c|c|c|c|c|}
\hline \multirow{3}{*}{ Sikap } & \multicolumn{4}{|c|}{ Tindakan Penanganan Limbah Padat } & \multirow{2}{*}{\multicolumn{2}{|c|}{ Total }} \\
\hline & \multicolumn{2}{|c|}{ Cukup } & \multicolumn{2}{|c|}{ Baik } & & \\
\hline & Frek & $\%$ & Frek & $\%$ & Frek & $\%$ \\
\hline Kurang & 1 & 2,04 & 1 & 2,04 & 2 & 4,08 \\
\hline Cukup & 3 & 6,12 & 6 & 12,25 & 9 & 18,37 \\
\hline Baik & 27 & 55,1 & 11 & 22,45 & 38 & 77,55 \\
\hline Total & 31 & 63,26 & 18 & 36,74 & 49 & 100 \\
\hline \multicolumn{7}{|c|}{ pvalue $=0,04$} \\
\hline
\end{tabular}

besar petugas kebersihan memiliki tindakan penanganan limbah padat cukup dengan sikap baik yaitu sebesar $55,1 \%$ (27 orang), tindakan dan sikap yang cukup sebesar $6,12 \%$ (3 orang), dan 2,04\% (1 orang) memiliki tindakan cukup dengan sikap yang kurang. Sedangkan untuk tindakan penanganan limbah padat baik dengan pengetahuan baik yaitu sebesar $22,45 \%$ (11 orang), tindakan baik dengan pengetahuan cukup sebesar $12,25 \%$ (6 orang), dan 2,04\% (1 orang) memiliki tindakan baik dengan pengetahuan yang kurang.

Berdasarkan analisis dengan menggunakan uji Kendall tau kurang dari $a=0,05$ yang berarti ada hubungan antara sikap dengan tindakan penanganan limbah padat pada petugas kebersihan di RSUD Syarifah Ambami Rato Ebu Bangkalan tahun 2018.

\section{PEMBAHASAN}

1. Tingkat Pengetahuan

Pengetahuan petugas kebersihan masih kurang mengetahui warna kantong plastik sampah medis dan kegunaan kantong plastik yang bermacam-macam warnanya yang digunakan di rumah sakit. Petugas tidak mengetahui tidak kapan harus melakukan pengangkutan limbah dan tidak mengetahui berapa lama 
penyimpanan sementara limbah medis.

Mayoritas responden memiliki pengetahuan yang baik terhadap pengelolaan limbah padat. Adapun faktor yang mempengaruhi tingkat pengetahuan yaitu pendidikan. Menurut Notoatmodjo, (2003) Semakin tinggi tingkat pendidikan maka akan semakin mudah menerima informasi sehingga makin banyak pula pengetahuan yang dimiliki.

Menurut Notoatmodjo (2011) Perilaku yang didasari oleh pengetahuan akan lebih langgeng daripada perilaku yang tidak didasari oleh pengetahuan.

2. Sikap

Hasil penelitian dapat memberikan gambaran bahwa sikap petugas kebersihan memiliki sikap yang baik terhadap penanganan limbah padat. Dengan sikap yang baik ini diharapkan tindakan penanganan limbah padat akan baik juga. Karena orang tersebut telah memiliki sikap yang positif untuk mendukung dalam melakukan suatu tindakan yang positif juga. Hal tersebut sesuai dengan teori Poedja
Wijatna bahwa pengetahuan yang baik cenderung akan memberikan tanggapan atau respon yang positif dan begitu juga sebaliknya (Notoatmodjo, 2003).

\section{Tindakan}

Tindakan petugas kebersihan di RSUD Syarifah Ambami Rato Ebu Bangkalan yang cukup sebesar $63,27 \%$ (31 orang) dan $36,73 \%$ (18 orang) mempunyai tindakan baik.

Mayoritas tindakan petugas kebersihan dalam melakukan penanganan limbah padat di RSUD Syarifah Ambami Rato Ebu Bangkalan adalah cukup. Hal tersebut dapat dilihat dari tindakan petugas kebersihan yang dilakukan selama bekerja seperti dibawah ini:

a. Melakukan pengangkutan sampah ketika volume sampah dalam keadaan penuh

b. Penggunaan troli, petugas kebersihan melakukan pengangkutan limbah dengan menggunakan troli dalam keadaan terbuka

c. Petugas kebersihan melakukan pengangkutan menggunakan troli yang sama antara sampah medis dan nonmedis. 
d. Petugas kebersihan meletakkan sampah medis dan nonmedis yang tidak terpisah antara limbah medis dan limbah nonmedis.

e. Tidak rutin dalam membersihkan tempat sampah setelah dipakai

Tindakan petugas kebersihan dipengaruhi oleh faktor-faktor lain yaitu fasilitas. Hal tersebut seperti yang dijelaskan oleh Sumantri (2010) suatu sikap belum otomatis terwujud dalam suatu tindakan (overt behavior) untuk mewujudkan sikap menjadi suatu perbuatan nyata diperlukan faktor pendukung atau suatu kondisi yang memungkinkan antara lain adalah fasilitas.

4. Hubungan pengetahuan petugas kebersihan dengan tindakan penanganan limbah padat

Tingkat pengetahuan petugas kebersihan memiliki hubungan terhadap tindakan penanganan limbah padat, semakin tinggi tingkat pengetahuan maka akan mempengaruhi semakin baiknya tindakan yang akan dilakukan. Hal tersebut sesuai dengan Notoatmodjo (2011) bahwa pengetahuan merupakan domain yang sangat penting untuk terbentuknya tindakan seseorang karena perilaku yang didasari oleh pengetahuan akan lebih langgeng daripada perilaku yang tidak didasari oleh pengetahuan.

5. Hubungan sikap petugas kebersihan dengan tindakan penanganan limbah padat

Menurut Notoatmodjo (2011) terbentuknya suatu praktik baru dimulai pada cognitive domain dalam arti subyek tahu terlebih dahulu terhadap stimulus yang berupa materi untuk pengelolaan sampah sehingga menimbulkan pengetahuan baru pada subyek terhadap pengetahuan tentang pengelolaan sampah. Pengetahuan dan sikap subyek terhadap praktek pengelolaan sampah diharapkan akan membentuk praktik atau tindakan (psikomotor) subyek terhadap praktek. 


\section{KESIMPULAN}

1. Tingkat pengetahuan petugas kebersih dalam penanganan limbah padat dengan kriteria baik sebesar $77,55 \%$

2. Sikap petugas kebersihan dalam penanganan limbah padat baik sebesar $77,55 \%$.

3. Tindakan petugas kebersihan dalam melakukan penanganan limbah padat sebagian besar adalah cukup yaitu sebesar 63,27\% dan baik sebesar $36,73 \%$.

4. Terdapat hubungan antara tingkat pengetahuan dan sikap petugas kebersihan dengan tindakan penanganan limbah padat di RSUD Syarifah Ambami Rato Ebu Bangkalan.

\section{SARAN}

1. Bagi Pihak Rumah Sakit

Perlu adanya pelatihan ataupun sosialisasi kepada petugas kebersihan tentang penanganan limbah padat (medis dan non medis) secara rutin dan diikuti oleh seluruh petugas kebersihan di RSUD Syarifah Ambami Rato Ebu
Bangkalan. Perlunya peraturan yang tegas pada petugas kebersihan dalam melakukan penanganan limbah padat agar tindakan yang dilakukan benar sesuai dengan Standar Operasional Prosedur dan peraturan yang telah ditetapkan oleh pihak rumah sakit.

2. Bagi Peneliti Lain

Dapat meneliti dengan menggunakan variabel yang lain seperti umur, pendidikan, dan lama kerja yang mempengaruhi perilaku petugas kebersihan terhadap tindakan penanganan limbah padat. Agar dapat digunakan sebagai pembanding dengan penelitian lain supaya menggunakan jenis penelitian dan metode yang lain.

\section{DAFTAR PUSTAKA}

Kementerian Kesehatan Republik Indonesia., 2017. Data Informasi Profil Kesehatan Indonesia 2016. Jakarta: Pusat Data dan Informasi. Keputusan Menteri Kesehatan Republik Indonesia., Nomor 1204 tahun 2004 Tentang Persyaratan Kesehatan Lingkungan Rumah Sakit.

Maharani, Annisa Fitri, Afriadi, Irvan, dan Nurhayati, Titing., 2017. Pengetahuan dan Sikap Tenaga Kesehatan Terhadap Pengelolaan Limbah Medis Padat Pada Salah Satu Rumah Sakit Di Kota 
Bandung. JSK, (Volume 3 Nomor 2).

Meilani, Yuni, dan Hidayanti, Lilik, dan Novianti, Siti. 2014. Hubungan Pengetahuan Dan Sikap Petugas Terhadap Praktik Pengelolaan Sampah Medis Di Rumah Sakit Umum Daerah Ciamis.

Notoatmodjo, Soekidjo., 2003. Prinsip-Prisip Dasar IImu Kesehatan Masyarakat. Jakarta, Rineka Cipta.

Kesehatan Masyarakat. Jakarta, Rineka Cipta. Cetakan Kedua Revisi

Sudiharti, Solikhah. Hubungan pengetahuan dan Sikap dengan Perilaku Perawat dalam Pembuangan Sampah Meds di Rumah Sakit PKU Muhammadiyah Yogyakarta. Jurnal Kesehatan Masyarakat Universitas Ahmad Dahlan. 2012

Sumantri, Arif., 2010. Kesehatan Lingkungan. Jakarta, Kencana Prenada Media Group 